\title{
BILATERAL CLEFT PALATE REPAIR BY USING TONGUE FLAP FOLLOWED BY ALVEOLAR BONE GRAFTING - A CASE REPORT
}

\author{
Memuna Kausar Satti, Zainab Qasim, Farwa Rais, Ayousha Iqbal, Maahin Shoaib*, Asad Ghaffar \\ Army Medical College/National University of Medical Sciences (NUMS) Rawalpindi Pakistan, *Private Clinic Rawalpindi Pakistan
}

\begin{abstract}
A clinical case of bilateral cleft palate repair using previous tongue flap followed by Alveolar Bone Grafting (ABG). After pre-surgical orthodontics a surgical procedure whereby previous tongue Flaps were reflected, nasal beds were prepared on both sides. A cortico-cancellous bone of $2 \mathrm{~cm}$ was harvested from iliac crest and grafted in clefts. Patient is kept on follow up to monitor healing, postoperative results and any post- operative complication.
\end{abstract}

Keywords: Alveolar bone grafting, Cleft lip and palate, Tongue flap.

This is an Open Access article distributed under the terms of the Creative Commons Attribution License (http://creativecommons.org/licenses/by/4.0), which permits unrestricted use, distribution, and reproduction in any medium, provided the original work is properly cited.

\section{INTRODUCTION}

Cleft lip and Palate, also called as orofacial cleft, one of the commonest groups of congenital malformations affecting head and neck ${ }^{1-3}$, that includes cleft lip (CL), cleft palate $(\mathrm{CP})$, or they may occur together (CLP) ${ }^{4}$. It is a congenital birth defect, whose severity may vary from a small groove on upper lip to a full non-integration of upper lip, primary and secondary palate ${ }^{5}$. Cleft lip and palate repair requires a series of surgeries and grafts which can be auto-grafts from a distant site. It involves both hard tissue grafts followed by soft tissue closure 6 . We report a clinical case of bilateral cleft palate repair using previous tongue flap followed by Alveolar Bone Grafting (ABG).

\section{CASE REPORT}

A male patient aged 10 years, presented in the Oral and Maxillofacial department of Armed Forces Institute of Dentistry on 15-12-2017, with the complaint of aesthetically unpleasing protruded anterior teeth causing social problems for the patient. The patient had a history of cleft lip in his relatives.

Patient had bilateral cleft lip and palate at birth, he went through cleft lip repair procedure at 6-months then cleft palate repair at age of one. ABG was planned at 7 years which was post-

Correspondence: Dr Memuna Kausar Satti, Dental Dept, Army Medical College Rawalpindi Pakistan

Received: 01 Dec 2019; revised received: 10 Mar 2020; accepted: 12 Mar 2020 poned due to decreased chances of graft survival as pre-maxilla was highly protruded. All past surgeries healed uneventfully supported by the analgesics and anti-biotics given post-op.

His General Physical Examination revealed normal vitals. Extra orally, a depressed nasal tip, columella and flared nares, protruded anterior pre-maxillary segment and teeth, scar mark on upper lip, incompetent lips and lower lip trap and a normal mouth opening.

Intraorally, a protruded anterior maxillary segment, narrow collapsed posterior maxillary segment, Tongue flap on palate, Bilateral cleft alveolus measuring right $0.5 \mathrm{~mm} \times 0.5 \mathrm{~mm}$, left $1.5 \mathrm{~mm} \times 1 \mathrm{~mm}$, deciduous teeth \#64 \#74 \#84 were present and permanent teeth \#12 \#21 were missing. Oral hygiene was satisfactory.

Pre-surgical orthodontic was done by expanding the maxilla with quad helix and removable appliance with screws. Tongue flap to close palatal fistula and create an adequate soft tissue base for later $\mathrm{ABG}$ was decided. Graft from iliac crest using previous tongue graft as a soft tissue base was adopted as the treatment plan. After preoperative patient assessment, preparation, obtaining adequate general anaesthesia and aseptic conditions, patient was draped and orotracheal intubation was done. Incisions were made around the clefts of both sides. Flaps were reflected, nasal beds were prepared on both sides. A corticocancellous bone of $2 \mathrm{~cm}$ was harvested from iliac 
crest and grafted in clefts. Flaps were closed with stitches of vicryl. Incision on iliac crest was closed in layers with $3 / 0$ vicryl. Foley's catheter was maxillary portion,facilitatingthe procedure of secondary corrective osteotomy if required, teeth eruption into cleft site and achieve desired

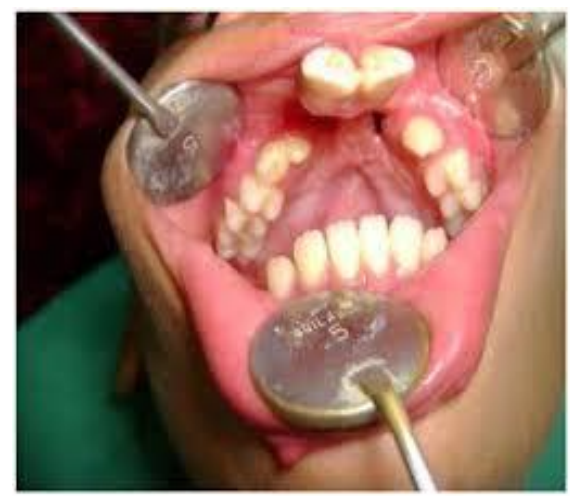

Figure-1: Pre-operative intraoral status.

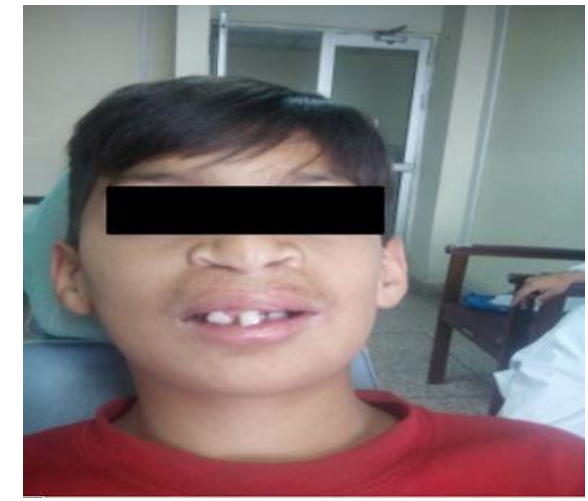

Figure-2: Post-operative extra oral

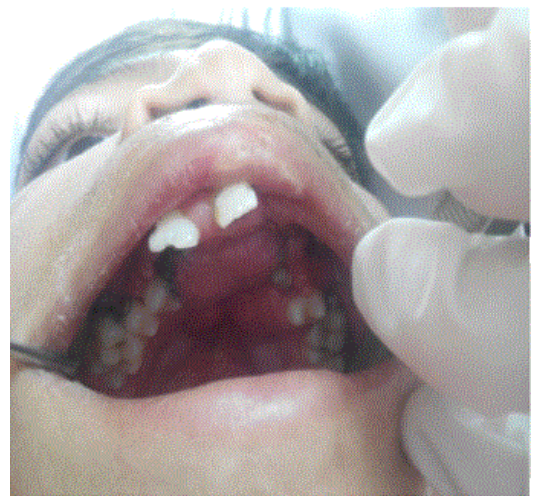

Figure-3: Post operative intra-oral status. kept in place. Drain was placed in iliac crest area. Throat pack was removed, instructions, antibiotics, anti-inflammatory and analgesics were given. Post-operative healing was uneventful. Patient is kept on follow up to monitor healing, postoperative results and any post- operative complication.

\section{DISCUSSION}

In the reported case age wise treatment protocol was adopted, Orthodontic procedure before surgery andCLP repair was carried out accordingly?

Tongue Flaps, popularized by Gersuny Eiselberg in 1901, are used to close intraoral defects including palatal fistulas owing to their excellent blood supply, low morbidity and potential to be used in irradiated patients. Although other options for flaps are available like cheek and nasal flaps these are generally bulky and leave scar. Other than these non-vascularized dermal grafts are also available but they are for defects less the $5 \mathrm{~mm}^{8,9}$. The rationale for using tongue graft in this case was to reduce scarring and providing a thin graft 6 .

ABGs provides a bony base to lessen nasal deformity, further advantages include oro-nasal and nasolabial fistula elimination thereby avoiding nasal reflux of fluid and air, Stabilizing movement tooth adjacent to cleft ${ }^{10}$. ABG is done in mixed dentition stage after eruption of permanent incisors but before eruption of permanent caninewhen growth inhibition effects of surgery are minimized, and it can help maxillary canine and lateral incisor to erupt through the cancellous bone ${ }^{11,12}$.

\section{CONFLICT OF INTEREST}

This study has no conflict of interest to be declared by any author.

\section{REFERENCES}

1. Newlands L. Secondary alveolar bone grafting in cleft lip and palate patients. British J Oral Maxillofacial Surg 2000; 38(5): 488-91.

2. Stasiak M, Wojtaszek-Słomińska A, Racka-Pilszak B. Current methods for secondary alveolar bone grafting assessment in cleft lip and palate patients-a systematic review. J Cranio-Maxillofacial Surg 2019; 47(4): 578-85.

3. Sharif F, Mahmood F, Azhar MJ, Asif A, Zahid M, Muhammad $\mathrm{N}$, et al. Incidence and management of cleft lip and palate in Pakistan. J Pak Med Associat 2019; 69(5): 632-39.

4. Shaw W, Semb G. The Scandcleft randomised trials of primary surgery for unilateral cleft lip and palate: 11 . What next? J Plast Surg Hand Surg 2017; 51(1): 88-93.

5. Colbert S, Green B, Brennan P, Mercer N. Contemporary management of cleft lip and palate in the United Kingdom. Have we reached the turning point. British J Oral Maxillofacial Surg 2015; 53(7): 594-98.

6. Fukuda M, Iino M, Takahashi T. Closure of large oronasal fistulas at the time of secondary bone grafting in patients with cleft lip and palate. Scand J Plastic Reconstruc Surg Hand Surg 2003; 37(6): 339-43.

7. Shaikh AH, Ibrahim MW, Bukhari G, Taqi M. Demographic profile of cleft lip and palate patients. Pak Oral Dental J 2017; 37(1): 16-18. 
8. Coghlan K, o'Regan B, Carter J. Tongue flap repair of oro-nasal fistulae in cleft palate patients. A review of 20 patients. J CranioMaxillofacial Surg 1989; 17(6): 255-59.

9. Vasishta SM, Krishnan G, Rai Y, Desai A. The versatility of the tongue flap in the closure of palatal fistula. Craniomaxillofacial Trauma Reconstruct 2012; 5(03): 145-60.

10. Cohen SR, Burstein FD, Stewart MB, Rathburn MA. Maxillarymidface distraction in children with cleft lip and palate: a preliminary report. Plastic Reconstruct Surg 1997; 99(5): 1421-28.

11. Roberts CT, Semb G, Shaw WC. Strategies for the advancement of surgical methods in cleft lip and palate. Cleft Palate-CranioFacial J 1991; 28(2): 141-49.

12. Weissler EH, Paine KM, Ahmed MK, Taub PJ. Alveolar bone grafting and cleft lip and palate: A review. Plastic Reconstruct Surg 2016; 138(6): 1287-95. 